\title{
Abuja, Nigeria, an Environmental Embarrassment: A Case of Spatial Dialectics
}

\author{
Onochie, A. O, Obiadi, Bons N, Nzewi N. U. \\ Department of Architecture, Faculty of Environmental Sciences, Nnamdi \\ Azikiwe University, Awka, Anambra State, Nigeria
}

\begin{abstract}
Urban development in Abuja, Nigeria, is growing without appropriate urban design principles and goals, resulting in urbanization, urban poor settlements both in the formal and informal areas of the city. The major threat to Abuja's proper development is more complex, more closely connected with the disarray and unprofessional practices in the implementation of the Master Plan. The process of urbanization in Abuja has been seen to rather produce what the present work could term "spatial dialectics" especially, in the spatial distribution of objects. This work aimed at heightening inadequacy of housing within the Abuja Federal Capital Territory that resulted in slums. The authors adopted qualitative research method that embraced information from secondary data sources. Abuja's urban development is an environmental embarrassment as a result, this work recommends linking the urban poor settlements with the Central City infrastructure and the urban economy. Adopting urban design principles, encourage high rise buildings.
\end{abstract}

KEYWORDS: development, population, housing, environment, urbanization

\section{Introduction}

In May 1967, Lagos emerged as both the Federal Capital of Nigeria as well as the capital of Lagos State with the creation of states and the continued retention of Lagos as the Federal Capital was seriously questioned. The dual role became a source of embarrassing political and administrative complications with the result of that, Lagos became not only unlivable and unserviceable, but also ungovernmeble (Nwafor, 1980, Okonkwo, 2006).
Nwafor (1980) stated that, as a result of the peripheral location of Lagos, the city has tended to acquire a 'regional' rather than a truly national capital where provincialism is stronger than the feeling of the nation's unity. In Nigeria where there is an urgent need to create a national identity and preserve the country as a political unit, the 'created capital' should be so located as to convey 'a feeling of locational and functional neutrality' (Nwafor (1980), citing Stephenson, 1970, Okonkwo, 2006).

The need to transfer the capital of Nigeria from Lagos to Abuja, came as a result of the former nation's capital, Lagos, being over crowded, congested and had no lands for expansion. Olaitan (2004) indicated that, the concept of Abuja as a befitting Federal Capital Territory, centrally located and without the defects of Lagos was spawned in 1975. According to Olaitan (2004), the Federal Capital City is located on the Gwagwa Plains in the northeastern quadrant of the Federal Capital Territory. It is bounded by the Abuja Hills to the east and the Zango-Kuku Hills to the south. The site for the Federal Capital City was chosen for its location at the center of the nation, its moderate climate, small population and also for political reasons. To accomplish the goal of relocating the Federal Capital to an area, geographically central to Nigeria and with relative equal accessibility to all parts of the nation, about 845 villages were displaced to make way for the Federal Capital Territory, FCT, (Olaitan, 2004). The government wanted an area, free of all encumbrances, a principle of "equal citizenship" within the territory where no one can "claim any special privilege of "indigeneity" as was the case with Lagos(Jibril, 2006, Okonkwo, 2006). 
It wanted all the existing population to be moved out of the territory. That was why it authorized not only a census of economic assets of all the inhabitants of the territory but also undertook to pay compensation for all their owners outside of the territory(Jibril, 2006, citing Mabogunje in Ayileka et al, 2001).

In the process of establishing a befitting new nation's capital, a Master Plan of the Abuja Federal Capital Territory was design. The resultant Master Plan was prepared such that land use, infrastructure, housing, transportation, recreation, economic and social services are coordinated and inter-related, Olaitan (2004), citing Abba (2003). Successive governments in Abuja have neglected these principles. As such, series of distortions to the concept, direction and implementation of the master plan are prevalent today (Olaitan, 2004).

According to Jibril (2006), the first major policy statement made by Government in 1976, when it decided to move the Federal Capital of Nigeria from Lagos (in the coastal area) to Abuja (in the central part of the country) was for complete relocation of the entire inhabitants outside the new Federal Capital Territory, of about 8000 square kilometers. This was aimed at freeing the territory from any primordial claims, and to enable Government take direct control, plan and develop the new city without any encumbrance, but that was not the case within the governments of Abuja. In making reference to the Abuja Master plan (FCDA, 1979), Olaitan (2004) indicated that, reference to the Abuja Master Plan reveals that in scope, besides including the major elements of the regional development plan for the Territory, the plan intended to regulate land use, transportation systems, infrastructure, housing and other services in a manner that recognized their interrelationships and spatial requirements which are paramount in any physical planning exercise of its magnitude.

According to the Abuja Master plan (1979), the development of the city was designed to be in four phases with a clearly defined target population of three million inhabitants. The city was designed as an efficient and attractive environment at each stage of its growth - from Phase 1, which was designed to accommodate 230,000 residents through Phases II and III, which were to accommodate 585,000 and 640,000 respectively, to Phase IV aimed at accommodating 1.
7 Million. Its ultimate population is estimated at 3.1 million (Olaitan, 2004). As it is the case with development implementation in most developing nations, Abuja Master plan was distorted, following different policy changes that affected Abuja.

According to Jibril (2006), "between 1976 and 2003, (a period of 27 years) there had been about four major policy changes affecting resettlement within the FCT." They are: (1), It was the original intent of the Abuja Master Plan to relocate the inhabitants, occupying the Federal Capital Territory area, however, careful enumeration later revealed that the figure was not 'few' - about 150,000 - 300,000 people. Uprooting such a huge population was thought to be unwise and could have delayed the takeoff of the project. It was then decided to allow the inhabitants to remain, but could be resettled within the territory, should their places of abode be affected by city development projects. (2), in some cases, at the time of relocation, plans were canceled for political reasons. While the people affected were fully prepared for movement to the new location, another policy change happened (Jibril, 2004). (3), in preparation for the 2003 general election, the additional security personnel brought into the Federal Capital Territory occupied the buildings under the resettlement scheme (plate 1.0). These major shifts in policy direction can be said to be the root cause of problems of squatters and Land Administration within the FCT (Jibril, 2006).

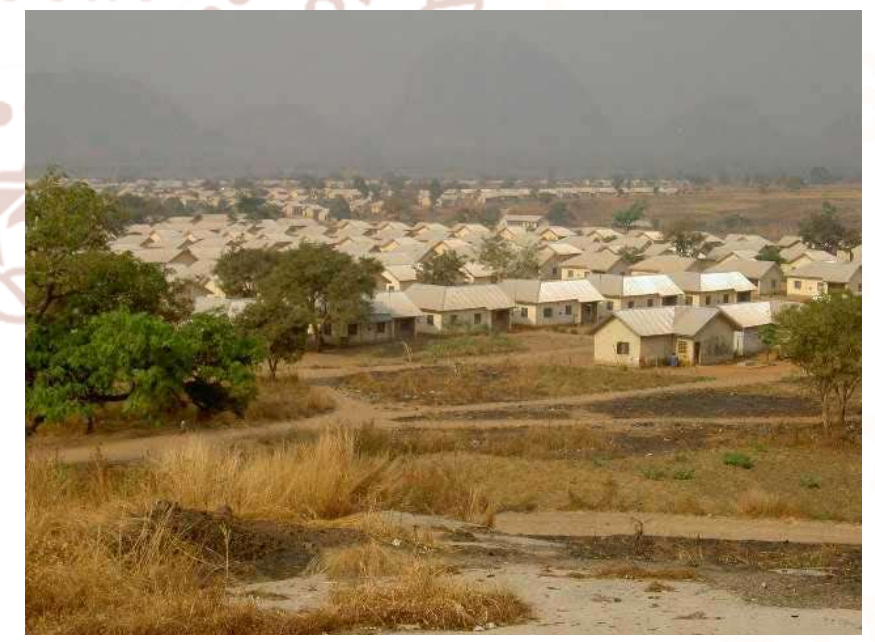

Plate 1.0. Resettlement village taken over by the Nigerian Police Force (fieldwork 2005)

Source: Jibril (2006)

(4). The derail and distortion of the Abuja Master Plan was also attributed to lack of professional personnel managing and planning the development of Abuja 
Master Plan. According to Jibril (2004), "the main cause of the distortions of the Master Plan was the creation of the Ministry of the Federal Capital Territory (MFCT) in 1980 and its being super imposed on the Federal Capital Development Authority (FCDA). The Ministry lacked the professional personnel to understand the philosophy of a Master Plan and the need for detailed planning and design to be carried out before the Master Plan could be transformed into construction activities in any part of the City."

Jibril (2004) further indicated that, "in 2003, a Ministerial Committee on Illegal Structures in the FCT was constituted to collate a list of all illegal structures in the FCT and present a strategy for demolition. Interestingly, most of the members of the committee were not professional planners."

(5), the unplanned territorial growth and developments occurring in the Central Area of the City could also be traced back to the governments rush to relocate the government workers from Lagos to Abuja. These problems are as a result of the rushed movement of workers from Lagos to Abuja without adequate provision for accommodation. The result was the emergence of a number of shantytowns and squatter settlements occupied by workers and the growing service population in such places as Karu / Nyanya, Karmo and Gwagwalada because there were not enough housing accommodations in the Central City area of Abuja to house them and the majority of the houses in the Central City were too expensive for the low income workers. These settlements have grown rapidly and are generally unplanned, overcrowded and lacking basic amenities and infrastructure. Although, many of the rushed housing developments within the city area have had to be demolished, the shanty developments persist in the periphery of Abuja especially as there is still little provision for housing accommodation for the lowincome workers within the city (Olaitan, 2004).

Adeponle (2013) observed "that Abuja city is growing faster $(13 \%)$ than the provisions of its Master Plan." It is fast turning into an environmental embarrassment, with developments springing up in gross isolation of zoning and other planning codes. Abuja, which was supposed to be an epitome of beauty and an enlightened vision of city development, has suffered over the years from unnecessary distortions in the implementation of its Master Plan. (Adeponle, 2013).
As a result of these changes in the Abuja Master Plan and policy inconsistences, the Abuja Central City designed to be a model city is not sustainable. It is divided between success and failures, rich and poor. It has potentials to flourish, but in most part, impoovished. The Central City is characterized by urban dialectics, dualistic living and infiltration of the formal settlement areas by informal settlers because of provision of services to the inhabitants of the formal settlement areas. There exist, a clear disparity in the socio-economic base of the two settlements yet, they co-exist. The two settlements co-existing within the formal settlement areas of the Central City are not integrated yet, because of nearness to their jobs and survival, the informal settlers infiltrating the formal settlement areas characterized as the urban poor, find their ways into the formal settlement areas of the Central City. In order to provide services and earn their living, the urban poor, through self-efforts, provide their shelters on government vacant lands, abandoned buildings and on city side-walks (plates 1.1 1.15). The informal settlement areas within the Central City of Abuja are not integrated into the Central City infrastructure and that is one of the major challenges of the city as a result, promoting urban poor growth that resulted in squatter settlements.

Plate 1.1. Abuja's public space (housing/shelter)

Source: the author (June 2016)

A typical space becomes the shelter/house and the house becomes the space (for most of these people who are security guards, their relations and friends) in the case of urban poor and urban poor housing in Abuja (plate 1.1). In most cases, these spaces are without spatially distributed objects yet, they are side by side with formal settlements without proper links and visually acceptable urban objects, elements and 
qualities. The nature of the socioeconomic complexity of these informal spaces, which analysis is shown in this work, constitute a strongly identifiable character which is in this work christened Spatial Housing. It is so termed because of the assumption of the public/open space into the provision of the basic (spatial) socioeconomic, psychological, shelter, etc. needs of the urban poor.

This phenomenon is different from those of the destitutes/homeless people in the city. The informal inhabitants are more or less fixed in location (even though improper location) and actively dependent on the socioeconomic activities of the urban economy. To that effect, Abuja urbanization is growing more than the area's urban development vis-à-vis housing and economic resources. In the formal sense, spaces can be defined and differentiated, however same cannot be said in the informal, hence 'spatial dialectics'. Within the space is the spatial housing characterized by informal volumetric and unvolumetric combination now called the 'spatial house', 'open house' or 'house without limit (plate 1.1, 1.11 to 1.13).

\section{All the Abuja government's housing programmes} have failed.

$>$ The housing provided by the Abuja government failed because of inadequacy of housing and a good access to the central facilities through a corridor of open spaces and lack of economic connectivity (secondary employment).

$>$ The Master Plan was prepared such that land use, infrastructure, housing, transportation, recreation, economic and social services were to be coordinated and inter-related (Olaitan, 2004, citing Abba, 2003), but that was not the case during the implementations.

$>$ Much of our daily experience of the city occurs within the collectively shared public spaces, or the public domain. Not only does the public domain provide for most basic of the city's functions, access, but it also provides for and contains many other functions and activities synonymous with urban life. These are lacking and the problem with Abuja's environmental and urban development.

$>$ Prior to 1973, government activities in public housing had been quite sectional and favored only the working class elites in the society. The poor and low-income were relegated to the background (Olu-Sule, 1988).
$>$ The Abuja government's housing programmes have not worked. The provided Federal Housing units were developed without adequate economic and municipal service facilities as a result, the housing units are not sustainable and also, inadequate for the Abuja steaming population. It equally fail because of the government rush to move government workers from Lagos to Abuja when the government has not provided adequate housing for the workers

$>$ Not only that, the Capital City was planned to be built by the Federal Government in its greater part. The Master Plan actually provided for lowincome settlements (housing) areas, to be built by the government and to be occupied by the public servants; the private sector servants did not appear to be properly provided for.

The government's approaches to solving the problems of the urban poor housing issues in Abuja Federal Capital Territory have not yielded a reliable solution; especially in the area of urban spatial distribution being created by the invasion of the formal by the informal urban dwellers; and to start solving them, this research explored sustainable spatial integration and retention of the urban poor settlement areas that architecturally bridged the gap (spatial solution) between the urban poor settlements (place of abode) and place of work; thus, evolving modalities for a sustainable spatial housing design for the urban poor in Abuja.

The derail and distortion to the Abuja master plan was also attributed to lack of professional personnel managing and planning the development of Abuja Master Plan and as supported by Jibril (2004), the main cause of the distortions of the Master Plan was the creation of the Ministry of the Federal Capital Territory (MFCT) in 1980 and it's being super imposed on the Federal Capital Development Authority (FCDA). The Ministry lacked the professional personnel to understand the philosophy of a Master Plan and the need for detailed planning and design to be carried out before the Master Plan could be transformed into construction activities in any part of the City. Jibril (2006) further indicated that, in 2003, a Ministerial Committee on Illegal Structures in FCT was constituted to collate a list of all illegal structures in the FCT and present a strategy for demolition. Interestingly, most of the members of the committee were not professional planners. In want of where to live, the urban poor and some workers, 
built makeshift homes anywhere the see land and that, became environmental embarrassment to the government.

Bello (2009) stated that, generally, as the population and affluence grow, there is an increase in the demand for land by government, private individuals and corporate bodies. Unfortunately, since the physical overall supply of land within a geographical area is fixed, demand always outstrips supply by a very wide margin, especially in the urban centers. This inevitably brings about the survival of the fittest syndrome. In this struggle, government has the upper hand through the exercise of their power of eminent domain, while individuals and corporate bodies meet their land requirements in the open markets. Within the open market, the corporate bodies and the rich individuals usually with higher bargaining power, dominate the transaction; while the urban poor are left with little or no choice but to make do with the crumbs. Consequently, this group of individuals, in most cases, occupies the less desirable areas such as marshy sites, neighborhood adjacent to refuse dumps and where they can find one, they encroach on government lands. The emergent settlement usually evolved as a spatial concentration of poor people in the poor areas of the cities. As expected, this settlement is usually characterized by infrastructure deficiencies, shanty structures, poor sanitation, urban violence and crime. These composition and characteristics have always made squatter settlement a source of worry and concern to their adjacent neighbors and governments (plate 1.2).

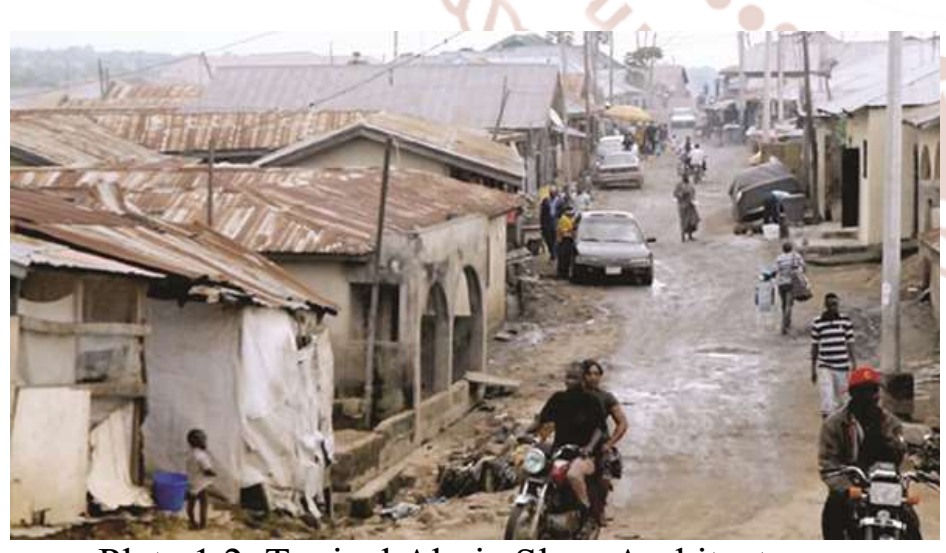

Plate 1.2. Typical Abuja Slum Architecture Source: Abuja Metro (2014).

As indicated by Bello (2009), the harbinger of squatting activities is inaccessibility of land engendered by low income of the urban poor. The end product is the creation of a slum. The effects of slums have been seen from various perspectives; the commonest one being on the deplorable environmental conditions.

Since Abuja became Nigeria's Federal Capital Territory in 1976; it has been experiencing rapid expansion, urbanization and significant changes in its physical landscape (Ujoh et al, 2010). The unplanned territorial growth and developments occurring in the territory could also be traced back to the governments rush to relocate the government workers from Lagos to Abuja as Olaitan (2004) agreed. These problems are as a result of the rushed movement of workers from Lagos to Abuja without adequate provision for accommodation. The result was the emergence of a number of shantytowns and squatter settlements occupied by workers and the growing service population in such places as Karu / Nyanya, Karmo and Gwagwalada. These settlements have developed rapidly and are generally unplanned, overcrowded and lacking basic amenities and infrastructure. Although, many of the rushed housing developments within the city area have had to be demolished, the shanty developments persist in the periphery of Abuja especially as there is still little provision for housing accommodation for the low-income workers within the city (Olaitan, 2004).

Adeponle (2013) observed that Abuja city is growing faster (13\%) than the provisions of its Master Plan. It is fast turning into an environmental embarrassment, with developments springing up in gross isolation of zoning and other planning codes. Abuja, which was supposed to be an epitome of beauty and an enlightened vision of city development, has suffered over the years from unnecessary distortions in the implementation of its Master Plan. Adeponle (2013) further indicated that, rapid urban expansion without effective environmental consciousness means that in virtually every urban center - from large cities and metropolitan areas to regional centers and small market towns - a substantial proportion of the population is at risk from natural and human induced environmental hazards.

Lack of accommodation has become the bane of most Abuja residents. During the Mallam Nasir el-Rufai administration of the Federal Capital Territory (FCT), many residents of Abuja lost their houses to the demolition exercise. That incident, however, contributed to the high cost of securing accommodation in the city center and even in the satellite towns. The influx of people into Abuja to look for greener pastures has helped to worsen the 
situation. To the average civil servant, securing a befitting accommodation in the FCT, irrespective of its location, is not only a challenge, but also an uphill task. Decent accommodation has continued to constitute a big problem to Abuja residents. Houses located at Garki, Maitama, Asokoro, Wuse, Jabi and Utako districts are practically beyond what the middle and low income earners can afford (Web Team, 2011). That resulted to concentration of squatter settlements in the Federal Capital Territory.

The questions are, who are the people mostly affected by the poor implementation of the Abuja Master Plan, Abuja demolitions and, the high cost of securing housing accommodation in Abuja and its territory? According to Bamidele (2010), most of the workers who cannot afford to live within the city, find their way to the squatter settlements and uncompleted or abandoned buildings within the city which punctuated all high-brow areas of the city and many. The people, according to Uji and Okonkwo (2007), frustrated by the inadequacies and failure of the conventional approaches to provide urban shelter and services to a significantly large enough proportion of the poor in the urban areas of the developing nations, these ever-increasing class of eurban populations have to resort to squatting on public or private land, either by invading and forcefully occupying or leasing such land (illegally sub-divided) on which they hurriedly construct (through self-help) their shelter from any available materials using any readily affordable and available technology.

In the past, various Federal Capital Territory (FCT) governments have tried, accommodating the interests of the Abuja, Nigeria urban poor settlements and without success. The government's approaches have not necessarily, extensively reviewed and investigated the ancestral concerns of most of the residents of the Abuja urban poor communities. A lot of government's solutions are centered around quick-fix urban renewal programmes that have not in anyway, helped the course of the urban poor communities and settlements in Abuja metropolis. The demolition exercises (several), resettlements and land swaps programmes adopted by the government have added more frustrations to the Abuja urban poor problems instead of solving them.

\section{Aim of the Study}

The aim of this work is to heighten the awareness of inadequacy of housing within the Abuja Federal Capital Territory and the impacts on the urban poor, characterized by infiltrating the formal settlement areas of the city, occupying marshy areas, abandoned buildings and vacant government lands with their make-shift homes (architecture). To point to the problems associated with the Abuja Master Plan, the distortions, rushed relocation from Lagos to Abuja without adequate development facilities, the use of unprofessional workers in the implementation of the Master Plan that resulted in urbanization, formal and informal settlements within the Central City, growth of unplanned settlements, thus, slums and squatter settlements (unplanned developments).

\section{Research Method}

This paper investigated the causes of the failure of architecture, urban development and urban development solutions, to improving the state of architecture in Abuja, Nigeria. As a result, authors adopted qualitative research method that embraced information from secondary data sources including, literature reviews from journals, previous works and books. The disciplinary area of focus is architecture, or better said, architecture and the urban environments as a result, the writers evaluated the opinions of the experts in the field and used that in supporting their argument that, Abuja, Nigeria, is an Environmental Embarrassment and a case of spatial dialectics.

\section{Architecture and Space Overtime}

This work looked at a new (approach) at identifying a new phenomenon in urban poor housing: 1. being the squatter issues with separate and demarcated territories. 2. Being the invasion of the urban formal areas by the urban poor. Thus, they live in the formal areas with their informal ways of life and this could be called the invasion of the formal by the informal.

In the development of Abuja, Nigeria, the urban actors did not examine urban design role(s) overtime and their historical focus regarding the understanding and importance of time and space in relationship with socio-economic issues of different countries, cities and towns. It required the study and understanding of the theories of architecture and urban planning as they influenced and impacted on human activities and the use of space (overtime) in both rural and urban areas of the world (Obiadi, 2017). 
According to Onofrei (2005), the theory of architecture considers the whole sphere of architecture as a study matter and has application infields belonging both to practice and to the knowledge. These are: architectural experience and architectural output (designing), to which we must add the architectural research, the history of architecture and architectural criticism. The theory enables us to understand the architectural experience, our perceptions in the "lived" architecture.

It also defines the factors which determine the creation of an architectural work and makes possible the critical estimate of the quality of a certain solution in a concrete case. The theory gives a conceptual base to the architectural research, pointing out its result to the effect that without a coherent theoretical basis, both architectural research and history of architecture lead only to knowledge without profoundness. Each of these application fields goes through its own dynamic process, and, in its turn, the theory of architecture; having multiple interconnections with them, is a complex subject in a continuous evolution (Onofrei, 2005).

It is a truism to say that architectures evolve over time. The term 'evolve' is however usually used quite loosely to mean that architecture changes over time and that it is possible to trace the sources of these changes to work produced by a previous generation of architects (Brown, 2006).

Each period offered something new and different because they were not all similar, but some/most of architecture was influenced from other periods/civilizations. Architecture captures the birth of new ideas to the scares of tragic events. Architecture has evolved from Greek to Roman to Modern Day. As time progresses, architecture advances, yet there are things that have retained conservative. This is done so that contemporary people may share the same experiences as the people in the prior time periods (Brown, 2006).

While it is not the intent of this work to get deep, into the evolution of architecture, it is rather important to understand architecture, how it evolved and the influence it will have on this work (Obiadi, 2017), Abuja, Nigeria, an Environmental Embarrassment: a case of spatial dialectics. Some scholars have suggested that the basis of urban life in Africa is so very recent in an historical sense, that we are still able to detect some of the early characteristics in many of the towns of contemporary Africa (Okonkwo, 1998 citing Gutkind, 1974). Both subsistence economy and nomadism still prevail over most of the continent today. Whether or not the prevalence of these early characteristics is widespread is a matter of less important in this work. Rather, of interest, is the presentation of an insight into the socioeconomic and sometimes political phenomena of urban development.

As man's attitude, towards the group, the community and society of which he is a member, has been changing throughout known history, so his reaction to his environment has passed through successive stages of transformation. Cities have played an important role in this process, which consists of a never-ending dialogue between challenge and response and which derives to strength and continuity from elementary thoughts of mankind-religion, exchange of ideas and goods and need for protection and gregarious living. For millennia human efforts have been directed, as far as cities are concerned, toward the same goal. Always and everywhere the basic elements of cities have been the same-dwelling houses, public buildings, and spaces between them. But the form and its meaning have changed, for both express the spiritual and intellectual conception of the universe that men have made for themselves (Okonkwo, 1998 citing Gutkind, 1974:11 - 12).

Today, the major threat to human environment is more complex, more closely connected with the very way in which cities are built. For example, the largest cities have grown nearly tenfold in a century. Yet, there consumption of land is greater still. An immense transport system is required. In the wealthier countries this bears strongly on the fact that masses of automobiles raise the level of air pollution and noise, and create serious problems of congestions and accidents. In poor countries where poor housing structures dominate the urban landscape, spaces are littered with settlements lacking the most basic urban infrastructures (plates 1.3 to 1.8). All these tend to reduce the quality of the human environment especially in the urban areas (Okonkwo, 1998: 32). 


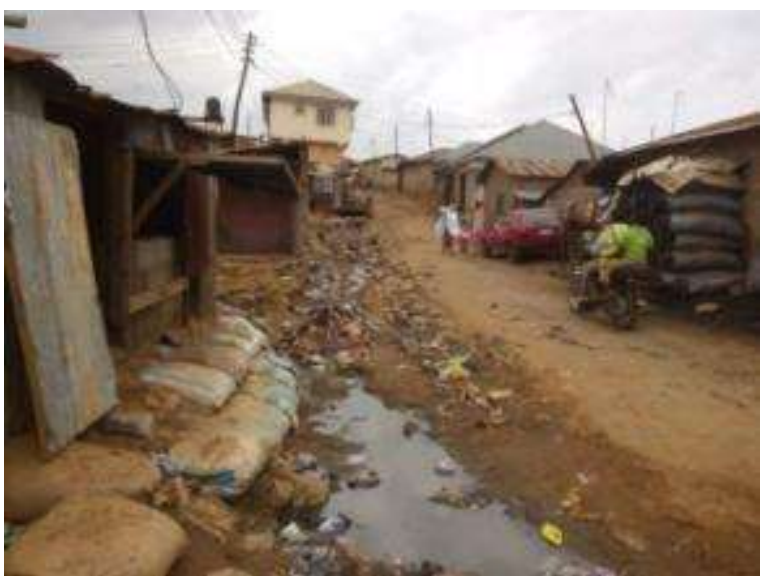

Plate 1.3. Better Life Area, Mpape

Source: BabajideOrevba (retrieved May 14, 2016)

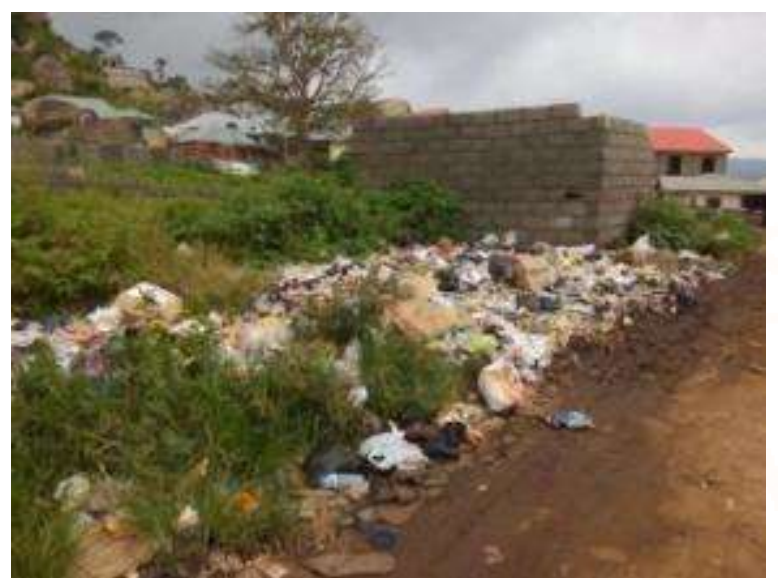

Plate 1.4. Berger Quarry Area

Source: BabajideOrevba (retrieved May 14, 2016)

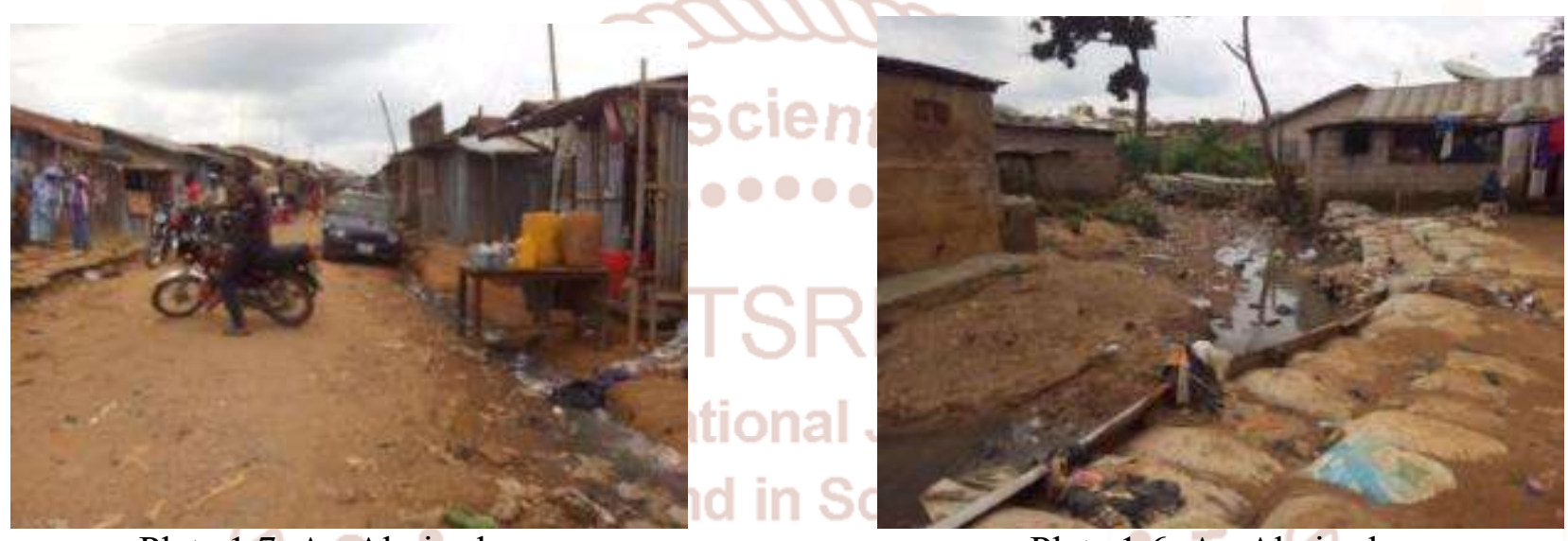

Plate 1.7. An Abuja slum

Plate 1.6. An Abuja slum

Source: BabajideOrevba (retrieved May 14, 2016)

Source: BabajideOrevba (retrieved May 14, 2016)

It is important to realize how these pressures resulting from development, on the urban geography mutually reinforce rather than correct one another. Although cities transform resources in ways that contribute strongly to economic development and social welfare, they also generate waste that pollute the urban-human environment and degrade renewable natural resources. A simple fact in this respect is that, though man's interaction with nature has brought about the formation of urban spaces and centers and their extension, the same process of interaction has also led to the degeneration of the spaces it created (plates 1.7 and 1.10). This is an important issue in housing and residential quantity and quality (Okonkwo, 1998: 33-34).

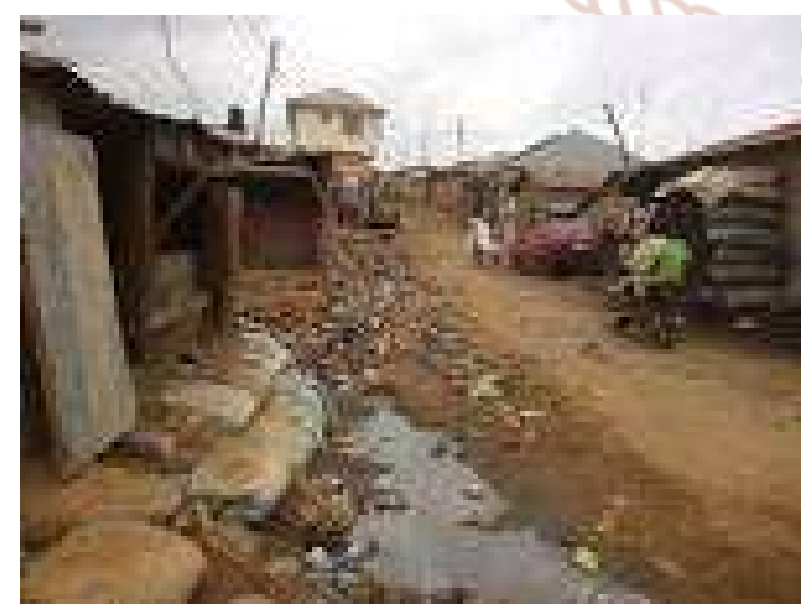

Plate 1.7. Alum, Mpape, Abuja

naij.com (retrieved May 14, 2016)

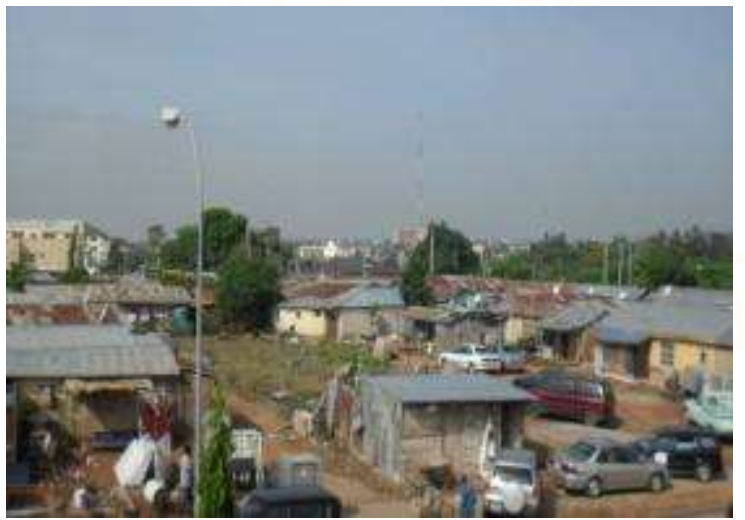

Plate 1.8. Utako Settlement area

Source: the authors 
In time and space, it was the first Industrial Revolution that brought to the limelight, for the first time, the failure of urban development and the problems of the urban poor. On historical focus of sociology and society, the process of industrialization and population growth compounded urban development failures (Okonkwo, 1998). Urbanization which occurs without adequate industrialization, sufficient formal employment or secure wages, has condemned burgeoning urban populations in the Third World to poor-quality housing. The problem has been compounded by lack of government funds for housing subsidies, by inflated land prices boosted by housing needs and speculation, and by real-estate profiteering on the part of the upper and middle classes. The operation of the class structure of Third World cities nowhere more geographical explicit than in the composition and working of the housing market. Only the small upper and middle classes in Third World cities have income, job security and credit worthiness to purchase or rent houses in properly surveyed, serviced and legally conveyed developments (Dickenson, 1983).

The problems and challenges posed by the rapid urban growth in Nigeria are immense. More easily observable and perhaps very frightening are the general human and environmental poverty, the declining quality of life and the underutilized as well as the untapped wealth of human resources. Housing and associated facilities (such as water, electricity, waste disposal) are grossly inadequate. Millions live in substandard environments called slums, plagued by squalor and grossly inadequate social amenities, such as, a shortage of schools, poor health facilities and lack of opportunities for recreation among others (plates 1.0 to 1.10). Juvenile delinquency and crime have become endemic in urban areas as a result of the gradual decline of traditional social values and the breakdown of family cohesiveness and community (Adepoju and Adetoye, 1995). All these are urbanization problems.

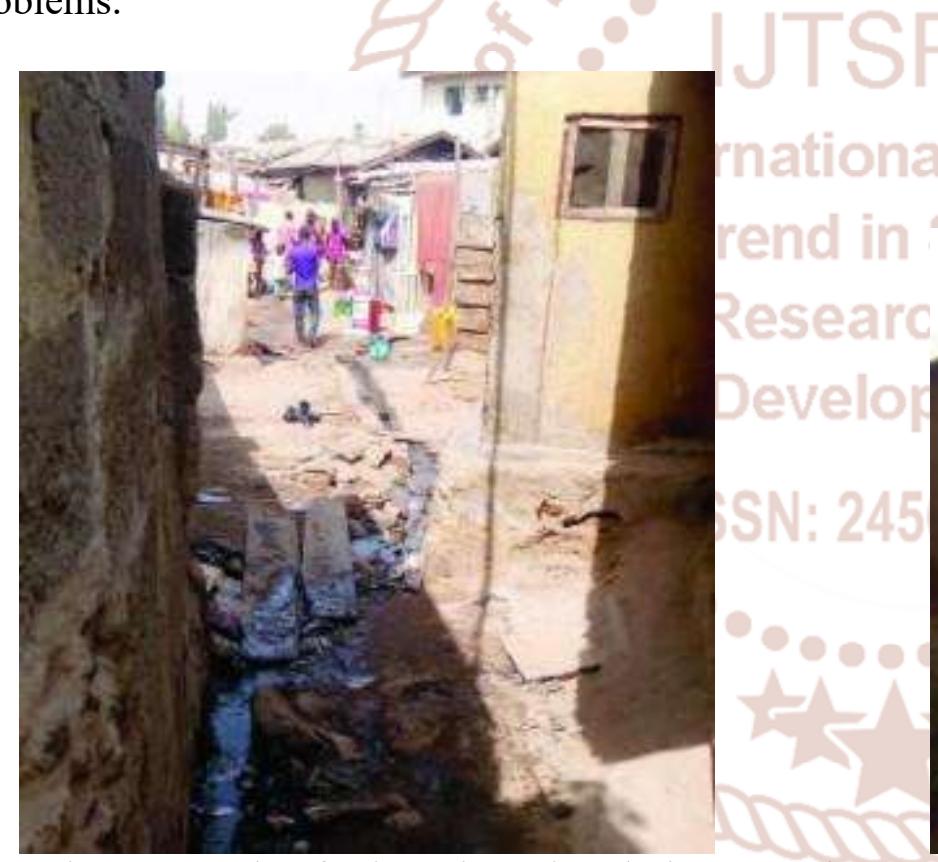

Plate 1.9. Tale of urban slums in Abuja mega city Source: Fred Itua, Nguamo Aka, Ruth Agada and AmakaAgu(retrieved May 14, 2016)

Urbanization is not a recent phenomenon in the history of Nigeria. Also, city growths date back into the country's pre-colonial era. Both urbanization and city growth have in the course of time been in relation to the level of the country's socio-economic development. Pre-colonial Nigerian cities recorded gradual growths in general terms. Where and whenever they existed their growths were associated with one basic feature: they controlled the spatial economic order; and provided spaces for cultural interaction. At colonization, the British introduced another socio-economic pattern of development characterized principally by a new hierarchy of administrative centers and a colonial export-oriented cash-crop economy. This resulted in the dislocation of the pre-colonial traditional urban economies and their system in Nigeria, thus affecting city development patterns. Cities then grew quite in relation to the impact of colonialism on the socio-economic life of 
the country. And most of Nigeria's major cities today emerged out of this colonial impact (Okonkwo, 2013)

However, in whichever form the making process of an urban center, town or city is examined one must contend with the complex nature of the subject because its political, social and economic implications are characterized by 'urban development' and 'urbanization,' which underscore, in a permanent way, the making of urban centers at any time, in any place and at any scale.

If urbanization could be summed up as the process of concentration of people and their socioeconomic activities within a place over a period of time, urban development does not depend on steady concentration and coalescence of urban facilities and services about a given center; it is fundamentally guided by man's reaction to his environment which passes through successive stages of transformation. However, while concentration process of people in a place (urban center) could be continuous and seemingly unstoppable, as is the case in Nigeria, the environmental transformation that accompanies it has important implications for proper understanding of the political, social and economic structure of the built environment of the place. As the form and meaning of the built environment are transformed and changed overtime, they both express the spiritual and intellectual conception of the universe which men have made for themselves, in response to human, organizational and institutional need (Okonkwo, 1998).

The emergence of Urban Design as both intellectual, professional and administrative instrument to address urban development failures can never be over emphasized. Architecture, urban planning and settlements cannot be reasonably discussed without fundamentally understanding the history of urban design, which ties them together. According Dalley (1989:20), the history of urban planning focuses on the people, places, concepts, and practices of planning of urban development over time.

According to Catanese and Snyder (1979), physical planning must now be defined to include all these diverse examples without excluding the more traditional focus upon the design of the "built environment." One such definition is that physical planning is the determination of the spatial distribution of human actions and conditions to achieve predetermined goals. This concept is the key to understanding the expanded role of physical planning.

All human actions and conditions are distributed in space: groups, cultural beliefs, buildings, vehicles, environmental pollutants, political power, energy consumption, skills, and technology. Any of these variables can be defined, observed, located, and translated into a map to show how they are distributed in space. Almost all urban planning activities sooner or later refer to a map showing the spatial distribution of critical variables that typically include population figures, economic and social conditions, and characteristics of the physical environment. Interest in the spatial distribution of activities and condition is not limited to urban planning. Many disciplines, including geography, architecture, engineering, economics, agriculture, sociology, anthropology, business, and public health use the concept of spatial distribution for solving problems.

Simply including spatial distributions in the analysis of an urban problem does not imply that physical planning is taking place. Only when a spatial distribution is part of an action recommended to achieve some purpose can we say that a physical plan is being proposed. For example, if a planner analyzes the socioeconomic conditions in areas of the city and recommends a social program which does not differentiate between areas, then there is no physical plan, only a social plan. However, if social programs vary among areas, there is a physical plan. What kinds of actions and conditions do planners spatially distribute, and for what purpose? There are essentially four types of variables whose spatial distribution is manipulated in physical plans: objects, functions, activities, and goals.

Within the context of physical planning, the spatial distribution of objects refers to items such as buildings, parks, trees, roads, highways, sewer lines, and utility plants. Spatially distributed objects may be as small as traffic signs and as large as airports. This aspect of physical plans comes closest to the traditional image of the urban planner. For example, the layout of pathways, residences, and marketplaces was a function of the planners in ancient Greece. Today planners are still actively engaged in planning the layout of suburban subdivisions, the design of new towns, and the location and distribution of parks, 
recreational facilities, hospital, schools, museums, libraries, and art centers.

There are other less obvious situations in which planners are concerned with the spatial distribution of objects. The location of a series of firehouses or ambulance stations is a form of physical planning in which objects are placed to achieve an effective distribution of critical public services. Large objects, such as industrial parks, highways, and shopping centers, also must be planned and located in space. Although the explicit functions of these objects are of paramount importance to the physical planner, they have many other attributes with which the planner must be concerned. For example, while an urban highway fulfills the function of transportation, because of its properties as a physical object it has a significant impact upon the quality of life within the neighborhoods through which it passes. Determining what impacts will occur and who will be affected is critical in the spatial distribution of such objects. Similarly, in the design of a downtown center the aesthetic qualities of the objects are as significant as the functions of the building. Thus the spatial distribution of objects is often an extremely complex problem that relates not only to the proper location of an object from the standpoint of its explicit purpose, but also to its form and visual quality, symbolic importance, and its interaction with other objects and human activities (Catanese and Snyder, 1979: 176178).

The complexity of this problem is made manifest in various noticeable attempts (formal and informal) by urban dwellers (both poor and rich) to provide housing for themselves in the city. Housing, according to Uji and Okonkwo, 2007 :17), Turner (1974), sees 'housing' as human dwelling, a roof over one's head meant to serve as shelter for human living, interaction and carrying out of activities away from in clemencies of weather. Uji and Okonkwo (2007) further indicated that, Turner (1974) associates housing with the process of responding to the needs for shelter and the associated demands of social services, health and public facilities which go with the physical shelter in order to ensure congruent living with the environment. Housing generally refers to the social problem of insuring that members of society have a home to live in, whether this is a house, or some other kind of dwelling, lodging, or shelter (Housing, 2013).

The process of urbanization of Abuja has been seen to rather produce what the present work could term "spatial dialectics" especially in spatial distribution of objects. The city is characterized by dual urban spaces: the formal (where all is organized) and informal (undeveloped squatter settlement). Overtime, both the formal and informal spaces have also developed an interdependent relationship. While the formal spaces are inhabited by the rich or those who could afford them, the urban poor are crowded in the informal urban spaces which dot mostly the central city areas of Abuja (see plate1.1 to 1.10). Thus the public spaces in these informal settlements have become or have assumed the function of "housing/shelter" for the Abuja urban poor (plates $1.11,1.12$ and 1.13).

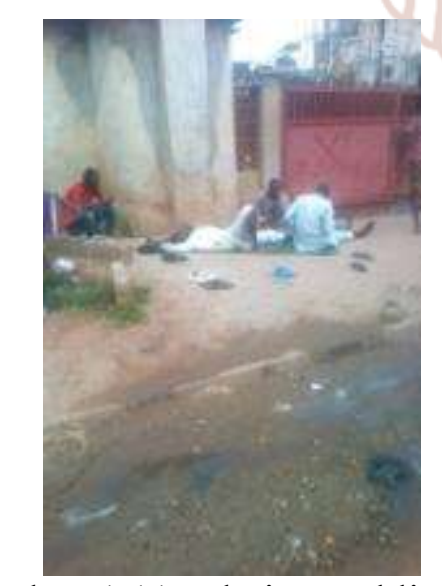

Plate 1.11. Abuja's public (housing/shelter) Source: the author

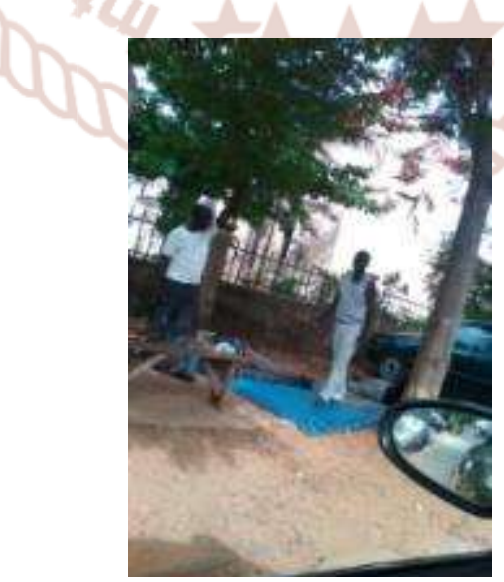

Plate 1.12. Abuja's public space (house/shelter) Source: the author

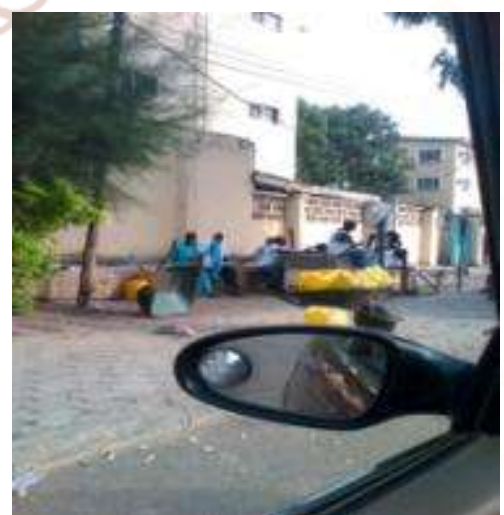

Plate 1.13. Abuja's public space space (housing/shelter)

Source: the author
A typical space becomes the shelter/house and the house becomes the space (for most of these people who are security guards, their relations and friends):the case of urban poor and urban poor housing in 
Abuja. They spend most of their time outside and outside becomes their home. Most times, they sleep on mats with mosquito nets over them. In most cases, these spaces are without spatially distributed objects yet, they are side by side with formal settlements without proper links and visually acceptable urban objects, elements and qualities. The nature, socioeconomic complexity of these informal spaces shown here, constitute a strongly identifiable character which is in this work christened Spatial Housing. It is so termed because of the assumption of the public/open space into the provision of the basic (spatial) socioeconomic, psychological, shelter, etc needs of the urban poor. This phenomenon is different from those of the destitutes/homeless people in the city. The informal inhabitants are more or less fixed in location (even though improper location) and actively dependent on the socioeconomic activities of the urban economy. However, economic growth in urban areas has not kept pace with the increase in the urban population (BBC, 2013). To that effect, Abuja urbanization is growing more than the area's urban development vis-à-vis housing and economic resources. In the formal sense, spaces can be defined and differentiated, however same cannot be said in the informal, hence 'spatial dialectics'.

As indicated earlier, urban objects includes buildings, parks, trees, roads, highways, sewer lines, and utility plants used by urban planners and architects in defining spaces. Space: is the boundless threedimensional extent in which objects and events have relative position and direction (Space, 2013). Within the space is the spatial housing characterized by informal volumetric and unvolumetric combination now called the 'spatial house', 'open house' or 'house without limit (Obiadi, 2017).

In a larger scale, the spatial housing would serve the interest of the Abuja urban poor, caught up in both Abuja's spatial dialectics and dualistic economy. The urban poor are equally known to live in the open, in shanty structures, marshy sites, and poor sanitary environments in want of where to live to stay close to work, both formal and informal. The urban poor inhabitants of "spatial housing" live within the formal areas while caving out their informal spaces within the same. According to Okonkwo and Agbonome (2012) citing Llyod (1979), the urban poor are considered to be inhabitants of shantytowns, slums and squatter settlements, who ordinarily, cannot afford, or have no access to means of meaningful existence. In order words, they generally are supposed to have no (or limited) access resources, employment and opportunities for self-improvement, education and advancement in the sense of modern technological developments.

Whether we call them unauthorized housing, informal housing, spontaneous or shelter settlements, they are settlements (usually in urban areas) also referred to as 'shantytowns' by Llyod (1979) who considered them as settlements found on land that may, usually, be illegally subdivided, with perpetual disregard for any form of urban settlement laws (Okonkwo and Agbonome, 2012 citing Llyod, 1979). In urban poor settlement locations, Okonkwo and Agbonome (2012) citing Osetereichh (1981), indicated that, because of uncontrolled nature and planleness of the development, buildings may either come too close to one another or obstruct and conflict with one another constituting serious potential fire hazard and making accesses to them also difficult, and provision of basic facilities almost impossibly expensive. Their own alternative facilities like deep wells and latrines also come into conflict with each other, posing serious fire hazards. They are usually characterized by physical forms that have acquired or become grime-and ratinfested, peeling paints and with surroundings littered garbage cans and refuse dumps, a generally depleted and unsanitary environment usually attributed to poverty of the occupant (plates 1.1 to 1.0, 1.14 and 1.15). 


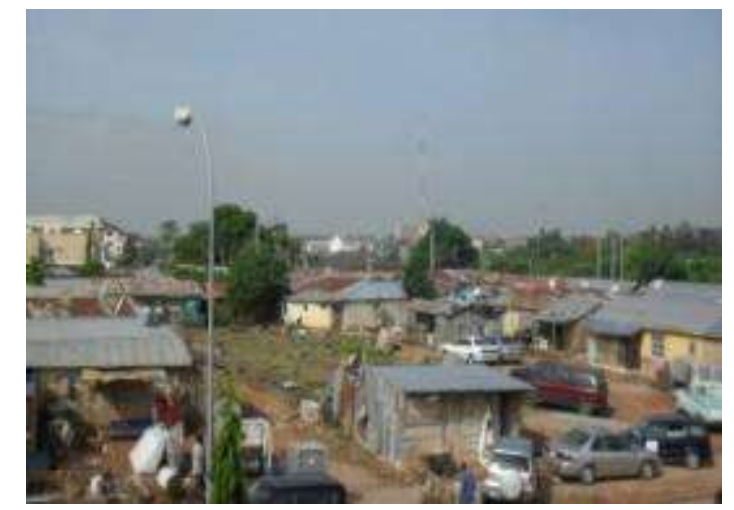

Plate 1.14. Utako, Abuja Settlement area

Source: the authors

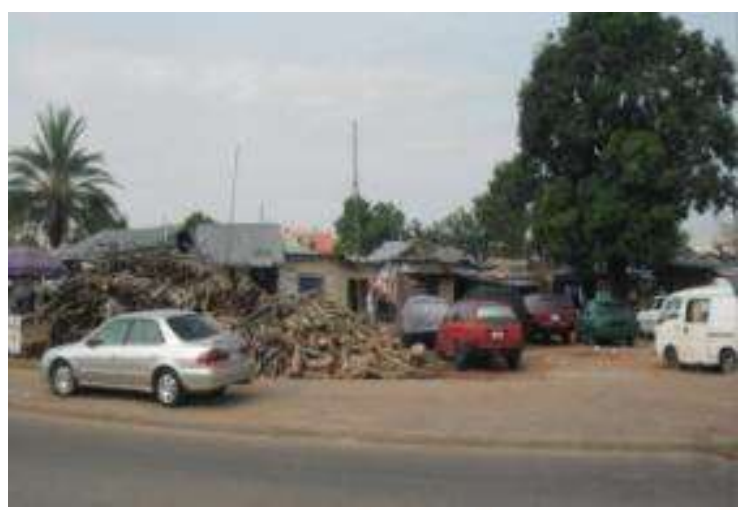

Plate 1.15. Utako Village, OkonjoIwulal Way Source: the authors
Whether or not it is clear, urban design can ameliorate the deeper problems of cities. But short of liquidation, what then is the future for urban design? It is arguable that it is ultimately the tasks of managing and improving the spatial dialectics. Expanding the concept of an inclusive, democratic, and civil domain will remain the critical challenge for urban design; the process may begin with solutions that are incremental and marginal in scope, but it must progress with larger vision of what needs to be accomplished (Loukaitou Sideris and Banerjee, 1998, 308), Sustainable Environment for the Urban Poor in Abuja, Nigeria.

\section{Conclusion}

As communities try joining the world class, it is important that they direct their attention to the problems of urbanization, homelessness, population and their consequences especially, as they affect human settlements, growth, development and the resources to sustain them. The population of the country is fast growing and so is the rural to urban migration putting pressure on both the housing industry and the existing infrastructure. To connect to the rest of the world, the government must start solving the population problems; provide the facilities needed to sustain the population growth, commerce, industry, tourism, social services and housing.

All over the world, including Nigeria, all the major cities are over populated, faced with inadequate housing, buildings in disrepair, traffic jams, bad roads, pressure on infrastructure, etc. With all these problems in mind, connecting to the world class would be farfetched until governments start working on sustainable spatial retention programmes, providing facilities that would create the much needed comfort zones for the people to settle down and start thinking clearly and fending for themselves. To achieve that, the government must start providing these facilities, using Abuja as a model city, the Abuja government must de-urbanize the city, provide the residents with reasonable paying jobs, provide housing, transportation, constant electricity, water supply, etc. These could be accomplished through good initiatives, government interventions, cooperative assistance and partnering with the people (privatization).

\section{Recommendations}

This work recommends linking the urban poor settlements in Abuja, Nigeria with the Central City infrastructure and urban economy. The government's approaches to solving the problems of the urban poor housing issues in Abuja Federal Capital Territory have not worked and to start solving them, this work recommends retention and sustainable spatial integration of the urban poor settlement areas $_{2}$ that would architecturally bridge the gap (spatial solution) between the urban poor settlements (place of abode) and place of work. It recommends adopting urban design principles, dealing with the density of the urban poor settlements, the aesthetics, urban amenities, well defined means of circulation, functional parks, how the urban poor settlement areas function and decongestion of the areas by building high rise and row houses. The buildings would embrace facilities for factories and industries (commerce) on the lower floors, where the residents would be gainfully engaged in economic activities while they live on the upper floors. Asian countries with limited lands and huge urban population problems solved their housing needs through vertical building approach and the model could be adopted in Abuja with huge housing needs (plates 1.16 and 1.17). 
A.

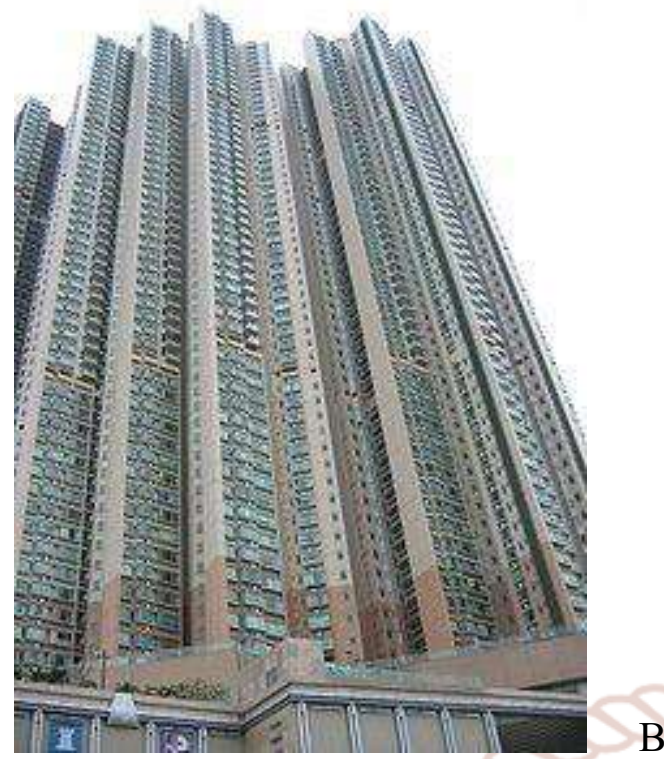

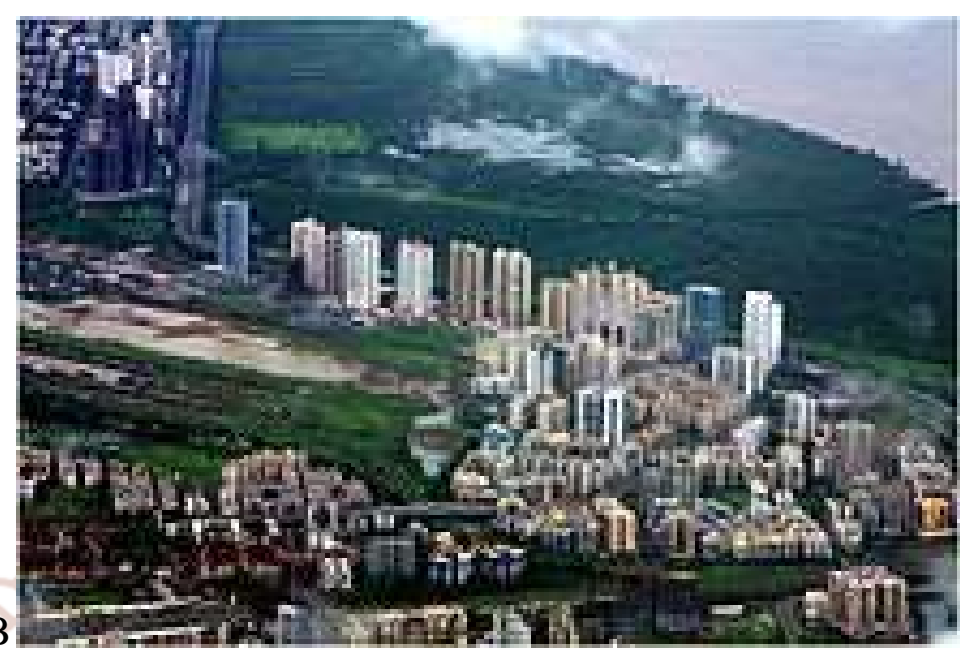

A. Plate 1.16. High-rise residential apartment, Hong Kong.

B. Plate 1.17. Numerious High-rise apartments in Navi Mumbai, India

Source: Internet (November 15, 2014)
The argument is, with the Abuja's epileptic electrical and water supplies, how can such proposal survive? There is nothing wrong with innovative endeavors. Almost all the Nigerian communities are flooded with boreholes, providing culinary water supply to the citizens. Dependency on public water supply has dwindled and fast becoming a thing of the past. The same scenario equally applies to electricity supply in virtually, all the Nigerian communities. Innovatively, electrical generator companies are producing efficient generators capable of steadily supplying electricity to large communities and uninterrupted. In most cases, rich and big companies that solely depended on electric generators for their electricity supply are doubling their generators in case of breakdowns. An added advantage is the invention and introduction of "inverters" (battery electric storage with capacity to generate electricity for a long period of time although, depending on the battery capacity).

The High-rise building approach if adopted, will work in Abuja, but the society must first, disabuse her mind that it will not work. If they work in advanced world, they will work in Abuja, Nigeria with abundance of high powered electric generators and high level of ground water for the boreholes.

\section{REFERENCES}

1) Abba. A (2003) Saving the City of the Abuja from Dir, Faeces, Garbage and Disease. In-depth Analysis Vol 3, N0 5 Nov 2003
2) Abuja Master Plan (1979). The Master Plan for Abuja.The New Federal Capital of Nigeria. Federal Capital Development Authority (FCDA), State House, Marina, Lagos, Nigeria.

3) Adepoju, O and Adetoye F. (1995). Urban Research in Nigeria. Institut Francais de Recherche en Afrique. Retrived from http://books.openedition.org/ifra/544?lang=en.

May 27, 2016.

4) Adeponle B.J (2013). The Integrated City as a Tool for Sustainable Development. Journal of Educational and Social Research Vol. 3 (5) August 2013

5) Ayileka, O. \& Kalgo, M.S.U(eds.) (2001), The Review of Abuja Master Plan:- Proceedings of an International Workshop for the Review of the Abuja Master Plan, held in Abuja, 9 November 2 December 1999. Ministry of the Federal Capital Territory, Abuja.

6) Bamidele Gbemiga (2010) Abuja: The Vexed Problem of Housing, newsdiaryonline.

7) BBC.2013. Lagos and its slum population

8) Bello, Mustapha Oyewole (2009). Squatter Settlement, Accessibility of Land and the Urban Poor.FIG Working Week 2009. Surveyors Key Role in Accelerated Development Eilat, Israel

9) Brown Alex (2006).The Evolution of Architecture. Retrieved from: http://www.alexbrown.net/2006/09/evolution-inarchitecture.html July 23, 2015 
International Journal of Trend in Scientific Research and Development (IJTSRD) ISSN: 2456-6470

10) Catanese Anthony J. and Snyder James C. (1997).Introduction TO Urban Planning. McGraw-Hill Book Company, New York

11) Dalley, Stephanie (1989). Myths from Mesopotamia: Creation, the Flood, Gilgamesh, and Others, Oxford World's Classics, London, p $120 \mathrm{p} 136$

12) Dickenson J. P., Clarke C. G., Gould W. T. S., Hodgkiss A. G., Prothero R. M., Siddle D. J., Smith C T., Thomas-Hope E. M. 1983. A Geography of the Third World. Methuen, London and New York.

13) Gutkind, Peter C. W. (1974). Urban Anthropology: Perspective on "Third World" Urbanization and Urbanism, Van Gorcum, Assn.

14)Housing (2013) Retrieved from: http://en.org/wiki/Housing

15) Jibril Ibrahim Usman (2006). Resettlement Issues, Squatter Settlements and Problems of Land Administration in Abuja, Nigerian's Federal Capital. Promoting Land Administration and Good Governance, $5^{\text {th }}$ FIG Regional Conference, Accra, Ghana.1-13.

16) Llyod P. (1979). Slumps of Hope? Shanty Towns of the Third World, Hamondsworth: Penguin Books Ltd.

17) Mabogunje, Akin (1968): Urbanization in Nigeria, University of London Press, London, pp.107-108.

18) Nwafor, J. C. (1980). Department of Geography, University of Nigeria, Nsukka, Nigeria. GeoJournal 4.4 359-336. Akademische Vetlagsgesellschaft, Wiesbaden

19) Obiadi, B. N. (2017). Evolving Modalities for Sustainable Spatial Housing Design for the Urban Poor in the Federal Capital Territory, Abuja, Nigeria. Department of Architecture, Faculty of Environmental Sciences, Nnamdi Azikiwe University, Awka, Anambra State, Nigeria

20) Okonkwo Moses M (2006). The Building of a New Capital and its Local Communities: Abuja Federal Capital City in Focus. Public Space as an Element in the Shaping of Local Societes. Urbanistyka Miedzyuczelniane Zeszyty Naukowe NR 11/2006. P68-85.

21) Okonkwo, M. M. (2013). Urban Development in Nigeria- A Post-SAP Period Pattern. Forth Dimension Publishing Co., Ltd

22) Okonkwo Moses M (1998). The Building of a New Capital and its local Communities: Abuja Federal Capital City on Focus. Department of
Architecture, Abia State University, Uturu, Nigeria.

23) Okonkwo M. M. and Agbonome P. C. (2012). Identifying and Housing of the Urban Poor in Nigeria: Adequacy of the "FEDUP" Approach. Architecture: Research and Practice. Journal of the Nigerian Institute of Architects, Enugu State Chapter. Vol. 2 No 2 April - September 2012, p 1 -13 .

24) Olaitan, Danmole Taibat (2004). Sustainability and City Development. A Critique of the Implementation of the Abuja Master Plan.Department of Urban and Regional Planning, University of Lagos, Akoka-Yaba, Nigeria.

25) Olu-Sule, R. A. 1988. Housing and Environmental Planning: A Synopsis on Urban Development in Nigeria. Wusen Press Ltd. 18 Ekpo Abasi Street, Calabar. P114-115

26) Onofrei, Virgiliu (2005). The Theory of ArchitectureApplications and Connections. Buletnul Institutului Politchnic Din Iasi, Tomuil Li (LV), Fasc. 3-4, Construch, Architectura.

27) Osetereich J (1981). "Positive Policies Towards Spontaneous Settlements," Ekistics Journal, 286, Jan/April.

28) Stephenson, G. V. (1970). Two Newly-Created Capitals: Islamabad and Brasilia. Town Planning Review 41, 317-332

29) Turner, J. F. C. (1974). Housing by the People, London: Marion Boyer. Normative and Prescriptive Interactions. Cambridge: university Press.

30) Uji Zanzan Akaka and Okonkwo Madubueze Moses (2007) Housing the Urban Poor, User Involvement in the Production Process, EDPCA Publications, Enugu, Nigeria, p11-17

31) Ujoh Fanan, Dlama Kwabe Isa andOluseyi Ifatimehin Olarewaju (2010).Urban expansion and vegetal cover loss in and aroundNigeria's Federal Capital City. Department of Geography and Environmental Management, University of Abuja, Nigeria.Department of Geography and Planning, Kogi State University, Anyigba, Nigeria. Journal of Ecology and the Natural Environment Vol. 3(1), pp. 1-10, January 2011Available online at http://www.academicjournals.org/jeneISSN 20069847 (C2011 Academic Journals.

32) Web Team (2011). Housing Problems in the FCTRetrieved from: www.ipledge2nigeria.com 